\title{
Combined treatment of atrial fibrillation with quinidine and beta-blockers
}

\author{
G. F. Levi and C. Proto \\ From the 4th Division of Medicine, Civil Hospitals, Brescia, Italy
}

Beta-blockers in combination with quinidine were given to 233 subjects with chronic atrial fibrillation. Conversion to sinus rhythm was obtained in 142 cases $(61 \%)$.

Propranolol was combined with quinidine in 122 subjects with a percentage of success of 64.8 per cent; alprenolol in 32 with a conversion to sinus rhythm of 56.2 per cent; LB 46 in 44 patients who responded in 65.9 per cent of the cases, and practolol in 35 with a re-establishment of sinus ${ }^{3}$ rhythm in 45.7 per cent of the patients.

In connexion with the duration of atrial fibrillation, the conversion to sinus rhythm was ob'tained in 76.4 per cent of the cases with a fibrillation of less than 6 months' duration and in 35.9 per cent with more than 6 months.

Toxic effects and intolerance to treatment are clearly less than with quinidine alone, which is probably due to a synergism between the two drugs, and as a consequence of the beta-blocker , depressant effects on ventricular excitability which avoids the onset of severe arrhythmias.

The treatment of chronic atrial fibrillation with DC shock which initially met with great enthusiasm, is now becoming less popular as a consequence of the complications (Resnekov, 1970) and fatalities ( $2 \%$, according to recent data: Resnekov, 1970), connected with DC conversion and the demonstration that most subjects $(72 \%$, according to Szekely, Sideris, and Batson, 1970) electrically converted to sinus rhythm show a relapsing fibrillation by the end of 12 months. Blanchot et al. (1969) discussed a return to quinidine therapy to reduce atrial fibrillation in cases of failure of external shock, and obtained 12 positive re- sults with quinidine in $2 \mathrm{I}$ patients where DC shock had failed to convert to sinus rhythm.

- In a recent paper (Levi and Proto, 1970b), we reported our results obtained in I22 patients with chronic atrial fibrillation with combined treatment with propranolol and quinidine; 64.6 per cent of patients were converted to sinus rhythm, and we came to the conclusion that this therapy 'is indicated in patients with atrial fibrillation because of the incidence of successful outcome, because sinus rhythm - can be maintained, because it is excellently tolerated, and because propranolol, with its depressant effect on ventricular myocardial excitability, provides a safeguard against the possibility of quinidine-induced syncope due to ventricular fibrillation'.

Received 29 November 197 I.
Subsequently we have treated groups of patients with an association of quinidine and more recently beta-blockers, such as alprenolol, LB 46, and practolol (Levi and Proto, I970a, 1972).

The chemical structure of these latest betablockers differs from propranolol particularly in the replacement of the naphtalenic nucleus with the indolic one for LB 46 (Lubawski and Wale, 1969) and a benzenic one for alprenolol and practolol (Brändström et al., 1966; Dollery, Paterson, and Conolly, 1969).

Pharmacologically, practolol differs from propranolol by the absence of a membrane activity or quinidine-like effect and by the presence of obvious cardioselectivity (Dunlop and Shanks, 1968) and, like alprenolol and LB 46 , by an intrinsic sympathicomimetic effect, lacking in propranolol (Hill and Turner, I969; Åblad, Brogård, and Ek, I967) (Table I).

TABLE I Comparison of effects of different beta-blockers

\begin{tabular}{lllll}
\hline & Beta-block & $\begin{array}{l}\text { Membrane } \\
\text { effect }\end{array}$ & $\begin{array}{l}\text { Intrinsic sym- } \\
\text { pathicomimetic } \\
\text { effect }\end{array}$ & Cardioselectivity \\
\hline Propranolol & + & + & - & - \\
Alprenolol & +++ & + & ++ & - \\
LB 46 & +++ & + & ++ & - \\
Practolol & ++ & - & + & ++ \\
\hline
\end{tabular}




\section{Methods}

All patients less than 70 years old with chronic atrial fibrillation of no more than 5 years' duration were included in the trial, with the following exceptions: patients not well compensated, patients with severe cardiomegaly or with disturbances of atrioventricular conduction, patients with 'giant left atrium', and those with severe pulmonary hypertension revealed by haemodynamic analysis.

Subjects with bronchial asthma and obstructive bronchopathies without respiratory insufficiency were treated with quinidine combined with alprenolol, LB 46 , or practolol, which, unlike propranolol, and because of their intrinsic betastimulating effect, have poor activity on bronchial smooth muscle.

We followed Stern's therapeutic schedule (Stern, I966) by administering a dose of betablocker every 6 hours for two to four days to reach an average ventricular rate of 60 to 80 beats $/ \mathrm{min}$. At this time quinidine was added (hydroquinidine I5 centigrammes with any single dose of betablocker). The combined treatment was carried on for another four to five days until atrial fibrillation was converted to sinus rhythm. To maintain sinus rhythm, treatment was continued indefinitely at slightly reduced doses.

The combined treatment was withdrawn after five to seven days when sinus rhythm failed to be achieved, or earlier in some rare cases of pharmacological intolerance.

Alprenolol, LB 46, and practolol were administered at a pharmacologically determined dosage, corresponding to the beta-blocking effect obtained with propranolol, $20 \mathrm{mg}$. The doses were propranolol $20 \mathrm{mg}$; alprenolol $50 \mathrm{mg}$; practolol 100 mg; LB 465 mg; 4 times a day.

The results of the trial confirmed that the therapeutic effects of these doses were the same. In fact we were able to show the similar effect of the 4 drugs by calculating the average reduction of heart rate in patients with re-established sinus rhythm (Table 2).

\section{Results}

A combination of quinidine and beta-blockers (Table 3) was administered to 233 patients with chronic atrial fibrillation. Of 122 patients treated with propranolol and quinidine, of whom 59 had coronary artery disease, 48 valvular heart disease, 8 idiopathic atrial

TABLE 2 Per cent decrease of cardiac rate with different combinations

\begin{tabular}{lllll}
\hline & $\begin{array}{l}\text { Proprano- } \\
\text { lol }\end{array}$ & $\begin{array}{l}\text { Alepreno- } \\
\text { lol }\end{array}$ & LB 46 & $\begin{array}{l}\text { Practo- } \\
\text { lol }\end{array}$ \\
\hline $\begin{array}{lllll}\text { Before } \\
\text { After }\end{array}$ & 91 & 97 & 94 & $95 \cdot 8$ \\
$\begin{array}{l}\text { Per cent } \\
\text { decrease }\end{array}$ & $59 \cdot 2$ & 62 & 60 & $63 \cdot 6$ \\
\hline
\end{tabular}

TABLE 3 Patients converted to sinus rhythm

\begin{tabular}{lclll}
\hline & $\begin{array}{l}\text { No. of } \\
\text { cases }\end{array}$ & $\begin{array}{l}\text { Converted } \\
\text { to sinus } \\
\text { rhythm }\end{array}$ & $\begin{array}{l}\text { Not } \\
\text { converted }\end{array}$ & $\begin{array}{l}\text { Per cent } \\
\text { in sinus } \\
\text { rhythm }\end{array}$ \\
\hline Propranolol & 122 & 79 & 43 & $64 \cdot 8$ \\
Alprenolol & 32 & 18 & 14 & $56 \cdot 2$ \\
LB 46 & 44 & 29 & 15 & $65 \cdot 9$ \\
Practolol & 35 & 16 & 19 & $45 \cdot 7$ \\
\hline Total & 233 & I42 & 91 & 60.9 \\
\hline
\end{tabular}

fibrillation, 6 thyrotoxic heart, and 2 congenital heart disease, sinus rhythm was re-established in 79 patients $(64.8 \%)$.

In 32 patients we tried to restore sinus rhythm with the association of alprenololquinidine, with a favourable result in 56.2 per cent of the cases ( 18 subjects). Of the 32 patients with chronic atrial fibrillation, 15 had coronary artery disease, I3 valvular heart disease, and 4 thyrotoxic hearts.

Of 44 patients treated with LB 46 - quinidine combination, 20 had sclerotic heart disease, I7 valvular heart disease, 4 idiopathic atrial fibrillation, 2 thyrotoxic hearts, and I luetic heart disease. Conversion to sinus rhythm was obtained $(65.9 \%)$ in 29 subjects.

The combination of practolol-quinidine was given to 35 patients, 18 of whom had sclerotic heart disease and 17 valvular heart disease; 16 responded $(45 \cdot 7 \%)$.

To provide evidence that the duration of atrial fibrillation is a key factor to the success of the therapy, we divided the patients into 2 groups according to the duration of arrhythmias (less or more than 6 months) (Table 4).

In the first group we obtained conversion to sinus rhythm in 84.4 per cent of cases with

TABLE 4 Duration of fibrillation as factor in determining success of conversion to sinus rhythm

\begin{tabular}{|c|c|c|c|c|c|}
\hline & $\begin{array}{l}\text { Duration } \\
\text { of atrial } \\
\text { fibrillation } \\
\text { (mth) }\end{array}$ & $\begin{array}{l}\text { No. of } \\
\text { cases }\end{array}$ & $\begin{array}{l}\text { Converted } \\
\text { to sinus } \\
\text { rhythm }\end{array}$ & $\begin{array}{l}\text { Not } \\
\text { converted }\end{array}$ & Per ce \\
\hline \multirow[t]{2}{*}{ Propranolol } & $<6$ & 66 & 56 & IO & $84 \cdot 8$ \\
\hline & $>6$ & 56 & 23 & 33 & $4 I \cdot I$ \\
\hline \multirow[t]{2}{*}{ Alprenolol } & $<6$ & $2 \mathbf{I}$ & 15 & 6 & $7 I \cdot 4$ \\
\hline & $>6$ & I I & 3 & 8 & $27 \cdot 2$ \\
\hline \multirow[t]{2}{*}{ LB 46} & $<6$ & $3 I$ & 25 & 6 & $80 \cdot 6$ \\
\hline & $>6$ & 13 & 4 & 9 & $30 \cdot 7$ \\
\hline \multirow[t]{2}{*}{ Practolol } & $<6$ & 26 & I4 & 12 & $53 \cdot 8$ \\
\hline & $>6$ & 9 & 2 & 7 & $22 \cdot 2$ \\
\hline Total & $\begin{array}{l}<6 \\
>6\end{array}$ & $\begin{array}{r}144 \\
89\end{array}$ & $\begin{array}{r}\text { I IO } \\
32\end{array}$ & $\begin{array}{l}34 \\
57\end{array}$ & $\begin{array}{l}76 \cdot 4 \\
35 \cdot 9\end{array}$ \\
\hline
\end{tabular}


propranolol, $7 \mathrm{I} \cdot 4$ per cent with alprenolol, 80.6 per cent with LB 46 , and 53.8 per cent with practolol; in the other group (patients with atrial fibrillation lasting more than 6 months) conversion to sinus rhythm was achieved in $4 \mathrm{I} \cdot \mathrm{I}$ per cent of cases with propranolol, 27.2 per cent with alprenolol, 30.7 per cent with LB 46 , and $22 \cdot 2$ per cent with practolol.

Of 142 cases converted to sinus rhythm, atrial fibrillation lasted for less than 6 months in 110 and for more than 6 months in 32; of 91 subjects who failed to return to sinus

- rhythm the atrial fibrillation lasted for over 6 months in 57.

Of 79 patients treated with the propranololquinidine combination with conversion to sinus rhythm, 56 were controlled after 6 months. 73.2 per cent maintained the sinus rhythm even when the combined treatment 3. was not followed constantly; this result is clearly better than those already reported for treatment with quinidine alone.

With the exception of sporadic ventricular extrasystoles, no electrocardiographic abnormality due to the drugs was observed during the trial either before or after conversion
(Proto et al., 1969, 1971). No sudden death due to cardiac arrest or ventricular fibrillation occurred in any of our subjects. We recorded quinidine-induced toxic signs in 4.8 per cent ( 9 cases) but never of a severe type ( 5 cases in the group treated with propranolol, 2 cases in the LB 46 group, $I$ in the group treated with alprenolol, and I with practolol). Cerebral embolism occurred in 2 patients treated with quinidine and practolol on the second and the fifth day after conversion to sinus rhythm. The treatment was continued with quinidine alone $400 \mathrm{mg}$ /day intramuscularly. The beta-blocker withdrawal caused serious electrocardiographic abnormalities, particularly with reference to QT and the morphology of the $T$ wave (Fig.), confirming that the beta-blockers probably provide a safeguard against some quinidine-induced electrocardiographic abnormalities.

For these reasons we think that treatment with quinidine-beta-blockers is a useful combination for chronic atrial fibrillation, because of the rapidity of response and its ability to maintain sinus rhythm; in particular, these drugs are pharmacologically compatible, and the depressant effect on ventricular excitability

FIG. Electrocardiogram in the course of the treatment with practolol-quinidine (a) and after withdrawal (b) of practolol.

(a)

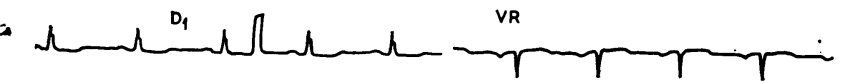

VL
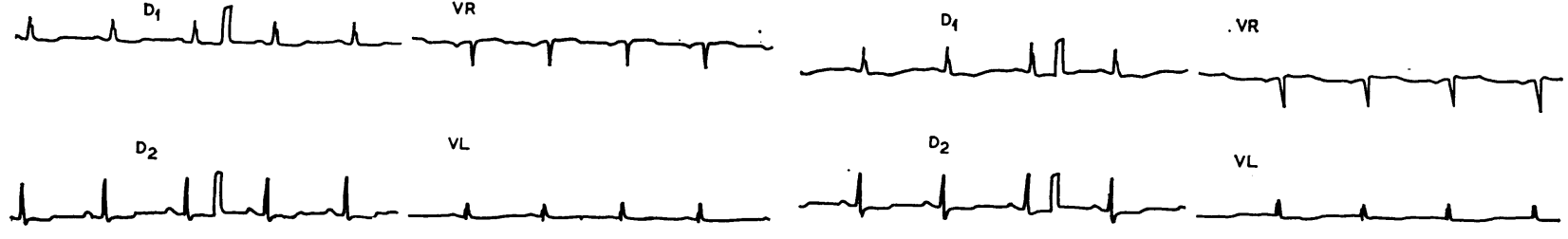
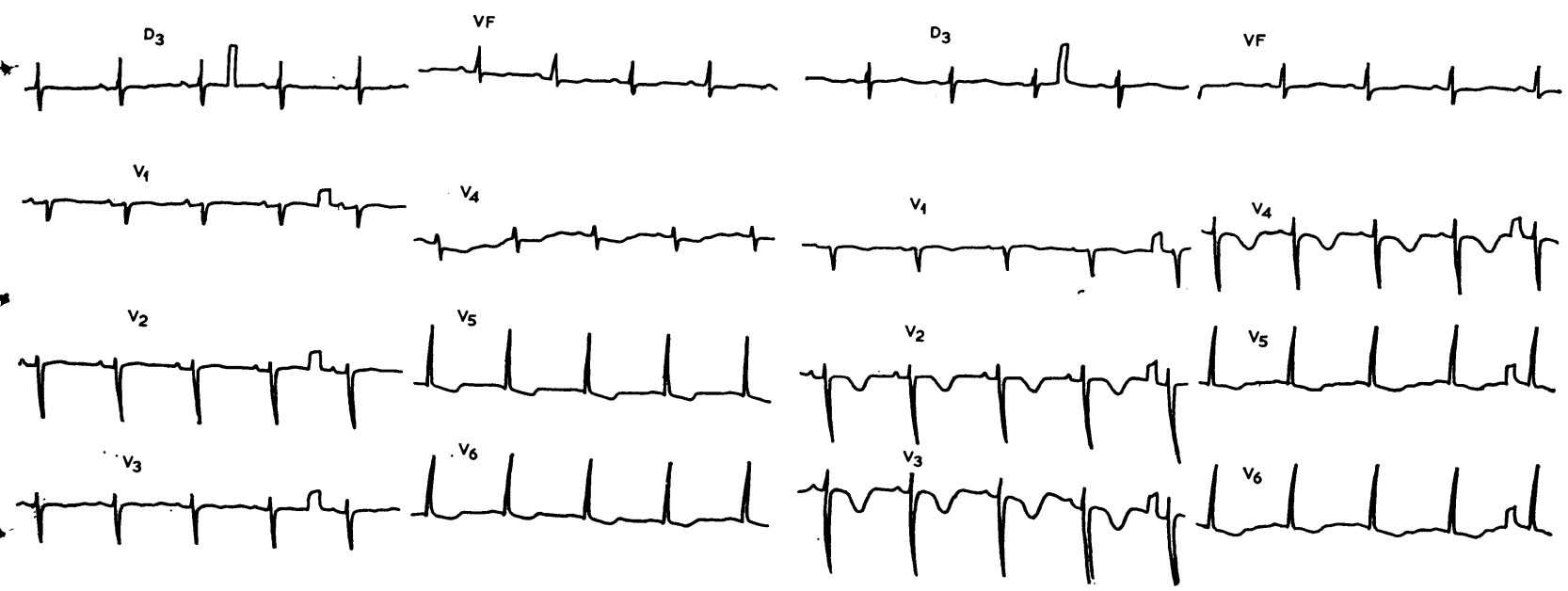
of the beta-blockers protects from quinidineinduced syncopes due to ventricular fibrillation.

With regard to a pharmacological tolerance superior to propranolol, the second group of patients treated with alprenolol, LB 46, and practolol cannot be perfectly compared with the first one. In fact, the second series included patients with chronic bronchopneumonia, who certainly could not be treated with propranolol and, in particular in those treated with practolol, the series included patients not perfectly compensated.

This may explain, together with the lack of membrane effect of practolol, a lower percentage of conversions to sinus rhythm than with the other beta-blockers.

In conclusion, the combination of betablockers and quinidine in the treatment of chronic atrial fibrillation is valid for the following three reasons.

I) No harmful effects from therapy: pretreatment with beta-blockers allows the use of hydroquinidine in small doses (about $20 \%$ of those usually employed) for a possible synergism between the two drugs.

2) The depressant effect of beta-blockers on ventricular excitability prevents the onset of severe arrhythmias.

3) The percentage of subjects who remain in sinus rhythm after 6 months is clearly higher than after electrical conversion.

\section{References}

Åblad, B., Brogård, M., and Ek, L. (1967). Pharmacological properties of $H$. $56 / 28 / a$ beta-adrenergic receptor antagonist. Acta Pharmacologica et Toxicologica, 25, Suppl. 2, 9.

Blanchot, P., Fontanille, P., Coumau, P., and Tisne, J. (1969). Retour au traitement par la quinidine après échecs des chocs électriques pour fibrillation auriculaire. Bordeaux Medical, 2, 5 II.
Brändström, A., Corrodi, H., Junggren, U., and Jonsson, T. E. (1966). Synthesis of some beta-adrenergic blocking agents. Acta Pharmaceutica Suecica, 3, 303.

Dollery, C. T., Paterson, J. W., and Conolly, M. E. (1969). Clinical pharmacology of beta-receptorblocking drugs. Clinical Pharmacology and Therapeutics, 10, 765 .

Dunlop, D., and Shanks, R. G. (1968). Selective blockade of adrenoceptive beta receptors in the heart. British fournal of Pharmacology and Chemotherapy, 32, 201.

Hill, R. C., and Turner, P. (1969). Preliminary investigations of a new-adrenoceptive receptor blocking drug, LB 46, in man. British fournal of Pharmacology, 36, 368.

Levi, G. F., and Proto, C. (1970a). Associazione alprenololo-chinidina per il trattamento della fibrillazione atriale cronica. Le Clinica Terapeutica, 55, II5.

Levi, G. F., and Proto, C. (1970b). Combined treatment of atrial fibrillation with propranolol and quinidine. Cardiology, 55, 249.

Levi, G. F., and Proto, C. (1972). Associazione di un nuovo beta-bloccante, LB 46 con idrochinidina per il trattamento della fibrillazione atriale cronica. Minerva Cardioangiologica, 20, 92.

Lubawski, I., and Wale, J. (1969). Studies with LB 46, a new beta-receptor blocking drug. European fournal of Pharmacology, 6, 345.

Proto, C., Quadri, A., Rovetta, A., and Levi, G. F. (1969). Trattamento combinato propranololo-chinidina della fibrillazione atriale cronica. Aspetti elettrocardiografici nei soggetti in ritmo sinusale ripristinato. Cardiologia Pratica, Suppl. 2-3, 129.

Proto, C., Levi, G. P., Quadri, A., and Levi, G. F. (1971). Associazione LB 46-chinidina nel trattamento della fibrillazione atriale cronica. Aspetti elettrocardiografici nei soggetti in ritmo sinusale ripristinato. Minerva Medica, 62, 2772.

Resnekov, L. (1970). Types of complications after DC shock. In Symposium Cardiac Arrhythmias, Elsinore, Denmark, p. 412. Astra, Södentälze, Sweden.

Stern, S. (1966). Synergistic action of propranolol with quinidine. American Heart fournal, 72, 569.

Szekely, P., Sideris, D. A., and Batson, G. A. (1970). Maintenance of sinus rhythm after atrial defibrillation. British Heart fournal, 32, 74I.

Requests for reprints to Dr. G. F. Levi, 4th Division of Medicine, Civil Hospitals, Brescia, Italy. 